\title{
Model Persediaan Multi Item dengan Mempertimbangkan Faktor Kedaluwarsa dan Faktor All Unit Discount
}

\author{
Taufik Limansyah ${ }^{1,2}$, Dharma Lesmono ${ }^{1}$
}

\begin{abstract}
This paper deals with determination of ordering policy for perishable goods, namely joint order policy or individual order policy. Expiration date is an important factor to be considered in the inventory system, especially in chemical or food industry. The problem becomes more complicated when the company has more goods with different expired dates. Another factor that has an influence to the inventory system is the supplier discount factor. A company can get benefit from this factor in order to reduce a total cost of inventory. In this paper, performance's criteria used for the selected policy is ordering policy that minimize the total cost of inventory by considering the expiration date and all unit discount.
\end{abstract}

Keywords: Inventory, ordering policy, expiration date, all unit discounts.

\section{Pendahuluan}

Persediaan berkaitan dengan penyimpanan suatu bahan baku/barang yang bertujuan untuk menunjang kelancaran suatu sistem produksi atau kegiatan bisnis yang dilakukan oleh sebuah perusahaan. Pengadaan persediaan yang terlalu banyak akan menyebabkan perusahaan mengeluarkan biaya yang besar untuk menyimpan bahan baku/ barang tersebut, seperti biaya perawatan, biaya sewa, atau biaya asuransi. Namun sebaliknya, pengadaan persediaan yang sedikit akan menyebabkan biaya pesan (setup cost) yang meningkat, kemungkinan terhentinya proses produksi akibat kekurangan bahan baku yang dapat mengakibatkan kehilangan pendapatan yang potensial, dan hilangnya kepercayaan konsumen karena konsumen berpindah pada perusahaan/produk lain.

Bagi perusahaan makanan atau industri bahan kimia, masa kedaluwarsa barang menjadi salah satu faktor yang juga mempengaruhi besarnya biaya total persediaan. Ketika barang tersebut telah melewati batas waktu pakai (barang telah kedaluwarsa), maka barang tersebut sudah tidak dapat digunakan lagi. Barang akan memiliki nilai jual yang lebih rendah seïring dengan mendekatnya masa pakai (waktu kedaluwarsa), bahkan tidak memiliki nilai jual sama sekali ketika barang tersebut telah kedaluwarsa.

\footnotetext{
1 Fakultas Teknologi Informasi dan Sains, Jurusan Matematika, Universitas Katolik Parahyangan, Jl Ciumbuleuit 94, Bandung 40141. Email: taufik.limansyah@unpar.ac.id

2 Program Pasca Sarjana, Magister Teknik Industri, Universitas Katolik Parahyangan, Jl. Merdeka 30, Bandung 40117. Email: jdharma@unpar.ac.id
}

Diterima 10 Juli 2011; revisi1 8 Agustus 2011; revisi2 26 Oktober 2011; revisi3 23 November 2011; revisi4 22 Desember 2011; diterima untuk dipublikasikan 23 Desember 2011
Pengadaan persediaan barang dengan waktu kedaluwarsa dalam jumlah yang banyak akan meningkatkan biaya kedaluwarsa bagi perusahaan. Perusahaan akan mengalami kerugian mengingat banyaknya barang yang memiliki nilai jual yang lebih rendah atau bahkan tidak memiliki nilai jual sama sekali ketika barang tersebut telah kedaluwarsa. Sebaliknya, jika pengadaan persediaan barang dengan waktu kedaluwarsa dalam jumlah yang sedikit akan mengakibatkan frekuensi pemesanan yang lebih sering sehingga biaya pemesanan menjadi mahal.

Model persediaan yang telah dikaji dan diulas pada berbagai buku dan literatur yang ada, seperti Tersine [10] yaitu model persediaan barang Economic Order Quantity (EOQ). Model EOQ ini merupakan model persediaan barang yang sederhana dan selanjutnya model ini menjadi dasar bagi pengembangan untuk model-model persediaan yang lebih kompleks. Berbagai model persediaan untuk barang-barang perishable telah dikaji dari berbagai sudut pandang yang berbeda-beda, seperti model mengenai pengendalian sistem produksi untuk satu jenis barang dengan laju penurunan nilai barang yang tidak pasti telah dikembangkan oleh Bukhari [1]. Ferguson et al. [2] memperluas model EOQ untuk barang-barang perishable dengan melihat biaya penyimpanan sebagai fungsi yang nonlinear dari waktu, sementara pada Indrianti et al. [4] telah dikembangkan model persediaan untuk satu jenis barang dengan mempertimbangkan faktor kedaluwarsa bahan. Selanjutnya model tersebut dikembangkan dengan menambahkan faktor unit diskon, baik all unit discount oleh Limansyah[6] dan Prasetyo et al. [9] ataupun incremental discount oleh Prasetyo et al. [8]. Kompleksitas permasalahan akan menjadi semakin berkembang ketika sebuah perusahaan memiliki banyak jenis barang dengan waktu kedaluwarsa yang berbeda-beda. Pada Muckstadt 
dan Saptra [7] serta Zang dan Wang [12] telah dikembangkan suatu model persediaan banyak jenis (multi item) yang memiliki masa pakai dengan melihat adanya keterbatasan kapasitas gudang untuk menyimpan barang-barang tersebut, sedangkan pada Hariga [3] mengembangkan suatu model untuk menentukan penggantian barang-barang pada pajangan/etalase, menentukan besarnya luas rak untuk masing-masing barang dalam memaksimumkan keuntungan bagi perusahaan dengan adanya keterbatasan luas rak. Kasthuri et al. [5] mengembangkan model multi item dengan penekanan pada ruang penyimpanan dan biaya produksi dalam lingkungan yang fuzzy. Zang dan $\mathrm{Du}$ [11] mengembangkan suatu sistem multi product newsboy untuk memenuhi permintaan yang tidak pasti. Namun dari model-model persediaan yang telah dikembangkan di atas, tidak banyak model-model persediaan barang yang mempertimbangkan kasus multi item dengan faktor kedaluwarsa barang dan quantity discount secara bersamaan. Hal ini merupakan kontribusi dari makalah ini terhadap pengembangan model-model persediaan untuk sistem persediaan multi item. Dalam makalah ini akan dilihat dari sudut pandang sisi kebijakan yang perlu diambil sebuah perusahaan dalam melakukan pemesanan barang sehingga diperoleh biaya total persediaan yang minimum.

Penentuan kebijakan pemesanan barang dapat dilakukan dengan dua cara, yaitu kebijakan pemesanan barang secara individu (individual order) dan kebijakan pemesanan barang secara bersama-sama (joint order). Kebijakan individual order berarti perusahaan melakukan pemesanan untuk masingmasing jenis barang secara terpisah dan tidak saling mempengaruhi antara barang yang satu dengan barang yang lainnya, sedangkan kebijakan joint order berarti perusahaan melakukan pemesanan secara bersama-sama untuk keseluruhan jenis barang. Masalah yang dihadapi perusahaan untuk menerapkan kebijakan joint order adalah pada saat kapan perusahaan harus mengajukan pemesanan barang secara bersama-sama sehingga biaya total persediaan menjadi minimum. Makalah ini mencoba menganalisa kebijakan tersebut untuk barangbarang yang memiliki faktor kedaluwarsa dan faktor all unit discount yang diberikan supplier. Kriteria performansi kebijakan yang dipilih adalah kebijakan yang meminimumkan biaya total persediaan.

Sistematika penulisan pada makalah ini diawali dengan pendahuluan. Selanjutnya pada bagian kedua membahas mengenai model persediaan barang dengan mempertimbangkan faktor kedaluwarsa barang dan faktor all unit discount dengan terlebih dahulu diberikan suatu gambaran mengenai model persediaan barang single item, dan kemudian dikembangkan suatu model persediaan multi item. Contoh ilustrasi masalah untuk model persediaan multi item dibahas pada bagian ketiga.

\section{Metode Penelitian}

Parameter-parameter yang digunakan dalam model persediaan multi item ini adalah

$P_{i} \quad$ : harga beli per unit barang untuk kuantitas tertentu (Rupiah)

$P_{i l}:$ harga beli per unit barang untuk jenis barang ke-l (Rupiah)

$D_{l} \quad$ : jumlah permintaan barang jenis ke- $l$ dalam satu periode perencanaan (unit)

$S_{l}$ : biaya pemesanan untuk setiap kali pesanan diajukan untuk jenis barang ke-l (Rupiah)

$S^{*}$ : biaya pemesanan untuk setiap kali pesanan diajukan jika melakukan kebijakan joint order (Rupiah)

$h_{l}$ : fraksi biaya simpan barang per unit per periode perencanaan untuk jenis barang ke- $l$

$C_{k l}$ : biaya kekurangan barang per unit untuk jenis barang ke-l (Rupiah)

$C_{k l}$ : harga jual per unit barang yang akan kedaluwarsa untuk jenis barang ke- $l$ (Rupiah)

$C_{p T}:$ total biaya pembelian selama satu periode perencanaan (Rupiah)

$C_{O T}$ : total biaya pemesanan selama satu periode perencanaan (Rupiah)

$C_{S T}$ : total biaya penyimpanan selama satu periode perencanaan (Rupiah)

$C_{S o T}$ : total biaya kekurangan selama satu periode perencanaan (Rupiah)

$C_{k d T}$ : total biaya kedaluwarsa selama satu periode perencanaan (Rupiah)

$t_{1}$ : periode penyimpanan barang sebelum kedaluwarsa (tahun)

$t_{2}$ : periode terjadinya kekurangan barang (tahun)

TAC : biaya total persediaan (Rupiah)

$U$ : batas jumlah barang yang dipesan dimana terjadi perubahan harga beli (unit)

$\theta_{l} \quad$ : fraksi barang baik untuk jenis barang ke-l. $\left(0<\theta_{l}<1\right)$

$1-\theta_{l}$ : fraksi barang yang akan kedaluwarsa untuk jenis barang ke- $l$

Variabel-variabel yang digunakan dalam model persediaan multi item ini adalah

$Q_{l}$ : jumlah pesanan yang optimum untuk jenis barang ke-l (unit)

$Q_{k} \quad$ : jumlah barang yang akan kedaluwarsa (unit)

$Q_{k l}$ : jumlah barang yang akan kedaluwarsa untuk jenis barang ke-l (unit)

$T^{*}$ : waktu antar pemesanan barang dari satu siklus ke siklus berikutnya (tahun) 
Dalam Limansyah [6] telah dikembangkan dan dibahas mengenai formulasi model persediaan barang satu jenis (single item) dengan melibatkan faktor kedaluwarsa dan all unit discount dan selanjutnya di bawah ini akan dijelaskan mengenai model persediaan barang single item dengan mempertimbangkan faktor kedaluwarsa dan faktor all unit discount sebagaimana yang telah disinggung pada Limansyah [6].

Gambar 1, menunjukkan bahwa tingkat persediaan tertinggi dicapai pada $Q^{*}$ unit, banyaknya barang yang akan kedaluwarsa sebanyak $Q_{k}$ yang terjadi pada akhir $t_{1}, L$, menyatakan lead time, $t_{2}$ menyatakan lama waktu terjadinya kekurangan barang, dan perusahaan harus melakukan pemesanan kembali ketika persediaan telah mencapai $B$ unit. Pada waktu $t_{1}$, perusahaan melakukan penjualan seluruh barang yang akan kedaluwarsa tersebut dengan harga yang lebih murah dan barang tersebut terjual habis. Selanjutnya di dalam model persediaan barang satu jenis, $T$ yang menyatakan satu periode perencanaan dalam Gambar 1 dimisalkan satu tahun.

Menurut Tersine [10], biaya total persediaan meliputi biaya pembelian (purchase cost), biaya pemesanan (setup cost), biaya penyimpanan (holding cost), dan biaya kekurangan (stockout cost). Secara garis besar, biaya total persediaan meliputi keempat komponen jenis biaya tersebut, namun tidak menutup kemungkinan terdapat komponen biaya-biaya lain yang mempengaruhi biaya total persediaan. Pada model persediaan satu jenis barang dengan melibatkan faktor kedaluwarsa dan all unit discount selain keempat kompenen biaya tersebut, juga terdapat komponen biaya lain yaitu biaya kedaluwarsa yang dapat mempengaruhi biaya total persediaan. Pada model ini juga terdapat faktor diskon yang diberikan oleh supplier pada biaya pembelian barang.

Biaya pembelian adalah biaya yang dikeluarkan untuk membeli bahan baku/barang. Dalam model persediaan ini terdapat faktor diskon yang diberikan supplier, maka besarnya harga beli per unit barang dapat didefinisikan sebagai berikut:

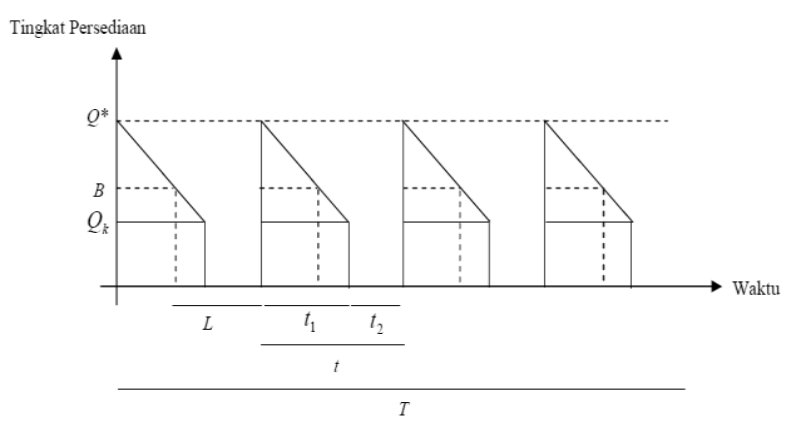

Gambar 1. Model persediaan barang dengan mempertimbangkan faktor kedaluwarsa barang
$P_{i}=\left\{\begin{array}{c}a_{0} \text { untuk } U_{o} \leq Q \leq U_{1} \\ a_{1} \text { untuk } U_{1} \leq Q \leq U_{2} \\ \ldots \\ a_{j} \text { untuk } U_{j} \leq Q \leq U_{j+1}\end{array}\right.$

dimana $a_{k}>a_{k+1}, k=0,1,2,3, \ldots, j$ untuk tiap unit barang. Jika dalam setahun terdapat permintaan sebesar $D$ unit, maka besarnya biaya pembelian dalam setahun adalah $C_{p}=P_{i} D$.

Biaya pemesanan adalah biaya yang dikeluarkan ketika sebuah pesanan diajukan. Jika besarnya biaya yang dikeluarkan untuk setiap kali pesanan diajukan sebesar $S$, maka besarnya biaya pemesanan dalam setahun adalah $C_{o}=S D / Q$.

Biaya penyimpanan adalah biaya yang dikeluarkan untuk keperluan pemeliharaan, sewa tempat, atau biaya asuransi atas barang/bahan baku yang ada. Jika besarnya biaya simpan per unit barang dinyatakan dalam fraksi dari harga beli barang per unitnya yaitu sebesar $P_{i} h$, maka besarnya biaya penyimpanan dalam setahun adalah $C_{s}=\frac{P_{i} h\left(Q^{2}-Q_{k}^{2}\right)}{2 Q}$

Biaya kekurangan (biaya pinalti) adalah biaya yang dikeluarkan karena kehabisan barang akibat adanya barang yang kedaluwarsa. Kekurangan barang terjadi selama periode waktu $t_{2}$. Jika besarnya biaya kekurangan per unit barang per satuan waktu adalah $C_{k}$, maka besarnya biaya kekurangan barang dalam setahun adalah $C_{s o}=\frac{C_{k} Q_{k}^{2}}{2 Q}$.

Biaya kedaluwarsa adalah biaya yang dikeluarkan karena barang telah melewati masa pakai. Dalam hal ini, biaya kedaluwarsa merupakan selisih antara harga beli barang $\left(P_{i}\right)$ dengan harga jual barang yang akan kedaluwarsa $(J)$. Jika harga penjualan per unit barang pada saat $t_{1}$ adalah $J$, maka besarnya biaya kedaluwarsa selama setahun adalah $C_{k d}=\frac{Q_{k}\left(P_{i}-J\right) D}{Q}$.

Biaya total persediaan selama 1 tahun yang terbentuk untuk model persediaan barang satu jenis adalah

$$
\begin{aligned}
\operatorname{TAC}\left(Q, Q_{k}\right)= & P_{i} D+\frac{S D}{Q}+\frac{P_{i} h\left(Q^{2}-Q_{k}^{2}\right)}{2 Q}+\frac{C_{k} Q_{k}^{2}}{2 Q}+ \\
& \frac{Q_{k}\left(P_{i}-J\right) D}{Q}
\end{aligned}
$$

dengan $S$ menyatakan biaya pemesanan untuk setiap kali pesanan diajukan dan $D$ menyatakan jumlah permintaan barang dalam satu periode perencanaan. Biaya total persediaan barang tersebut akan minimum untuk

$Q=\sqrt{\frac{2 S D}{P_{i} h}+\frac{\left(P_{i}-J\right)^{2} D^{2}}{P_{i} h\left(P_{i} h-C_{k}\right)}}$ dan 
$Q_{k}=\frac{\left(P_{i}-J\right) D}{P_{i} h-C_{k}}$

Prosedur untuk memperoleh jumlah pemesanan barang yang optimal bila terdapat faktor kedaluwarsa barang dan faktor all unit discount dengan tujuan meminimunkan biaya total persediaan dilakukan dengan menggunakan algoritma berikut (Prasetyo et al. [9]):

1. Hitung $Q$ pada setiap tingkat unit harga pembelian barang.

2. Bandingkan $Q$ dengan $U$. Jika $Q$ berada dalam interval $U\left(U_{j} \leq Q \leq U_{j+1}\right)$, maka $Q$ valid dan lanjutkan ke langkah (4).

3. $Q$ tidak valid (berada di luar interval $U_{j} \leq Q \leq$ $\left.U_{j+1}\right)$, maka

(i) Jika $Q \leq U_{j}$, gunakan $Q=U_{j}$

(ii) Jika $Q>U_{j}$, gunakan $Q=U_{j+1}$

4. Hitung banyaknya barang yang kedaluwarsa $\left(Q_{k}\right)$.

5. Hitung $T A C$ untuk setiap $Q$ yang valid dan semua $U$ yang mungkin dari langkah (3).

6. Bandingkan hasil perhitungan $T A C$ untuk $Q$ yang valid dengan $T A C$ untuk semua $U$ yang mungkin

7. Pilihlah jumlah pesanan $(Q)$ yang memberikan nilai $T A C$ paling minimum.

Selanjutnya dari model Limansyah [6] dikembangkan suatu model persediaan barang dengan mempertimbangkan faktor kedaluwarsa dan all unit discount untuk banyak jenis barang. Asumsi-asumsi dalam model persediaan multi item ini adalah (1). Tingkat permintaan barang diketahui dengan pasti dan konstan sepanjang waktu, (2). Barang-barang yang dipesan berasal dari supplier yang sama, (3). Lead time (waktu tunggu) pemesanan diketahui dan konstan, (4). Jumlah pemesanan setiap barang selalu sama pada setiap pemesanan, (5). Kekurangan barang akan terjadi pada saat barang yang akan kedaluwarsa terjual habis, (6). Masa pakai (kedaluwarsa barang) diketahui dengan pasti, (7).

Seluruh barang yang akan kedaluwarsa langsung terjual dengan harga yang lebih murah, sehingga mengakibatkan tidak adanya biaya simpan.

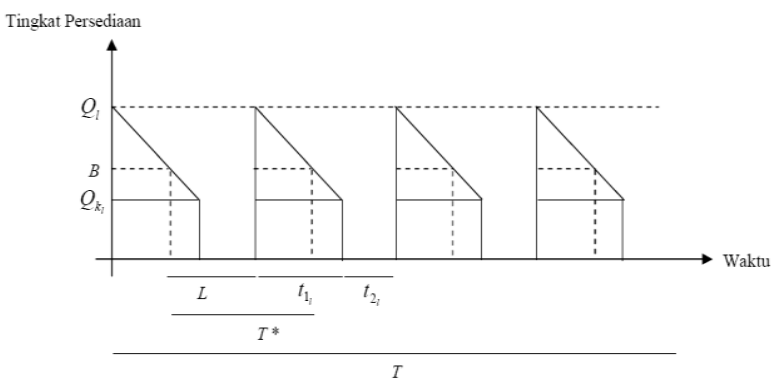

Gambar 2. Model persediaan barang dengan kebijakan joint order
Pada Gambar 2, $T^{*}$ menyatakan waktu antar pemesanan barang dari satu siklus ke siklus berikutnya. Asumsikan bahwa $T$ adalah satu tahun, didapat $Q_{l}=D_{l} T^{*}, \quad t_{1 l}=\frac{Q_{l}-Q_{k l}}{Q_{l}} T^{*}$, dan $t_{2 l}=\frac{Q_{k l}}{Q_{l}} T^{*}$. Jika $\theta_{l}=\frac{Q_{l}-Q_{k l}}{Q_{l}}$, maka $Q_{k l}=Q_{l}\left(1-\theta_{l}\right), t_{1 l}=\theta_{l} T^{*}$,dan $t_{2 l}=\left(1-\theta_{l}\right) T^{*}$. Untuk kebijakan joint order, faktor waktu pemesanan keseluruhan barang secara bersama-sama menjadi sangat penting. Hal ini dikarenakan akan mempengaruhi besarnya biaya total persediaan. Dengan perkataan lain, $T^{*}$ menjadi indikator utama yang mempengaruhi biaya total persediaan.

Dalam Limansyah [6], dikemukakan bahwa biaya total persediaan untuk satu jenis barang dengan mempertimbangkan faktor kedaluwarsa dan faktor all unit discount merupakan penjumlahan dari biaya pembelian, biaya pemesanan, biaya penyimpanan, biaya kekurangan, dan biaya kedaluwarsa. Kelima komponen biaya ini tetap digunakan untuk masalah persediaan dengan banyak jenis barang, namun yang berbeda tampak pada biaya pemesanan jika perusahaan melakukan kebijakan joint order. Dengan demikian, secara matematika biaya total persediaan selama 1 tahun untuk banyak jenis barang dapat dinyatakan sebagai berikut:

Biaya Total Persediaan $=\sum$ Biaya Pembelian + Biaya Pemesanan dengan joint order $+\sum$ Biaya Penyimpanan $+\sum$ Biaya Kekurangan + $\sum$ Biaya Kedaluwarsa.

Biaya pembelian adalah biaya yang dikeluarkan untuk membeli bahan baku/barang. Dalam model persediaan ini terdapat faktor diskon yang diberikan supplier, maka besarnya harga beli per unit barang untuk masing-masing jenis barang dapat didefinisikan sebagai berikut:

$P_{i l}=\left\{\begin{array}{c}a_{0 l} \text { untuk } U_{o l} \leq Q \leq U_{1 l} \\ a_{1 l} \text { untuk } U_{1 l} \leq Q \leq U_{2 l} \\ \cdots \cdots \\ a_{j l} \text { untuk } U_{j l} \leq Q \leq U_{(j+1) l}\end{array}\right.$

dimana $a_{k l}>a_{(k+1) l}, k=0,1,2, \ldots, j$ dan $l=1,2, \ldots, n$. Jika dalam setahun terdapat permintaan sebesar $D_{l}$ unit, maka besarnya biaya pembelian dalam setahun adalah $C_{p T}=\sum_{l=1}^{n} P_{i l} D_{l}$.

Biaya pemesanan adalah biaya yang dikeluarkan ketika sebuah pesanan diajukan. Jika besarnya biaya pemesanan dengan joint order yang dikeluarkan untuk setiap kali pesanan diajukan sebesar $S^{*}$, maka besarnya biaya pemesanan dalam setahun adalah $C_{o T}=S^{*} / T^{*}$. 
Biaya penyimpanan adalah biaya yang dikeluarkan untuk keperluan pemeliharaan, sewa tempat, atau biaya asuransi atas barang/bahan baku yang ada. Jika besarnya biaya simpan per unit masing-masing barang dinyatakan dalam fraksi dari harga beli masing-masing barang per unitnya yaitu sebesar $P_{i l} h_{l}$, maka besarnya biaya penyimpanan dalam setahun adalah $C_{S T}=\sum_{l=1}^{n} \frac{P_{i l} \theta_{l}\left(T^{*} D_{l}+T^{*} D_{l}\left(1-\theta_{l}\right)\right)}{2}$.

Biaya kekurangan (biaya pinalti) adalah biaya yang dikeluarkan karena kehabisan barang akibat adanya barang yang kedaluwarsa. Kekurangan barang terjadi selama periode waktu $t_{2 l}$. Jika besarnya biaya kekurangan per unit masing-masing barang per satuan waktu adalah $C_{k l}$, maka besarnya biaya kekurangan barang dalam setahun adalah $C_{S o T}=$ $\sum_{l=1}^{n} \frac{C_{k l} T^{*} D_{l}\left(1-\theta_{l}\right)^{2}}{2}$.

Biaya kedaluwarsa adalah biaya yang dikeluarkan karena barang telah melewati masa pakai. Dengan perkataan lain, perusahaan akan melakukan penjualan seluruh barang yang akan kedaluwarsa dengan harga yang lebih murah pada saat $t_{1}$ sehingga menyebabkan perusahaan akan mengalami kerugian. Dalam hal ini, biaya kedaluwarsa merupakan selisih antara harga beli barang $\left(P_{i l}\right)$ dengan harga jual barang yang akan kedaluwarsa $\left(J_{l}\right)$. Jika harga penjualan per unit masing-masing barang pada saat $t_{1 l}$ adalah $J_{l}$, maka besarnya biaya kedaluwarsa selama setahun adalah $C_{k d T}=\sum_{l=1}^{n} D_{l}\left(P_{i l}-J_{l}\right)\left(1-\theta_{l}\right)$.

Akibatnya biaya total persediaan untuk model persediaan multi item ini adalah

$$
\begin{aligned}
\operatorname{TAC}\left(T^{*}\right)= & \frac{S^{*}}{T^{*}}+\sum_{l=1}^{n}\left[P_{i l} D_{l}+\frac{P_{i l} \theta_{l}\left(T^{*} D_{l}+T^{*} D_{l}\left(1-\theta_{l}\right)\right.}{2}+\right. \\
& \left.\frac{C_{k l} T^{*} D_{l}\left(1-\theta_{l}\right)^{2}}{2}+\sum_{l=1}^{n} D_{l}\left(P_{i l}-J_{l}\right)\left(1-\theta_{l}\right)\right]
\end{aligned}
$$

Selanjutnya untuk mencari biaya total persediaan yang minimum, haruslah dipenuhi kondisi $d T A C / d T^{*}=0$ dan diperoleh

$$
T^{*}=\sqrt{\frac{S^{*}}{\sum_{l=1}^{n}\left[\frac{P_{i l} h_{l} \theta_{l} D_{l}\left(2-\theta_{l}+C_{k l} D_{l}\left(1-\theta_{l}\right)^{2}\right.}{2}\right]}}
$$

Prosedur untuk memperoleh waktu pemesanan barang yang optimal bila terdapat faktor kedaluwarsa barang dan faktor all unit discount dengan tujuan meminimunkan biaya total persediaan dilakukan dengan mengembangkan algoritma untuk persediaan single item dari Tersine [10], yaitu:

1. Hitung $T^{*}$ untuk setiap kombinasi tingkat harga pembelian dari tiap-tiap barang.

2. Tentukan $Q_{l}$, dimana $Q_{l}=T^{*} D_{l}$ pada setiap tingkat harga pembelian masing-masing barang dan hitung TAC dengan menggunakan persamaan (4).
3. Pilih nilai $T^{*}$ yang memberikan $T A C$ minimum dengan jumlah pemesanan barang yang sesuai dengan tingkat harga pembelian yang diberikan oleh supplier.

4. Tentukan $Q_{k l}$, dimana $Q_{k l}=Q_{l}\left(1-\theta_{l}\right)$.

\section{Hasil dan Pembahasan}

Suatu perusahaan menjadi agen penjualan untuk tiga buah jenis makanan dari distributor yang sama. Masing-masing indikator dari ketiga jenis makanan dan harga penawaran tiap unit yang diberikan oleh distributor ditunjukkan oleh Tabel 1 dan Tabel 2.

Perusahaan menghendaki untuk mengeluarkan biaya total persediaan minimum. Untuk itu diperlukan suatu strategi kebijakan yang perlu dilakukan oleh perusahaan tersebut.

Jika perusahaan melakukan kebijakan pemesanan barang secara individu (individual order), maka dengan menggunakan algoritma pada Prasetyo et. al [9] dan persamaan (1), (2), (3), jumlah pemesanan barang yang optimal dan biaya total persediaan untuk masing-masing ketiga jenis makanan diberikan pada Tabel 3.

Jika perusahaan melakukan kebijakan individual order untuk ketiga jenis makanan tersebut, maka biaya total persediaan yang dikeluarkan selama 1 tahun adalah $\operatorname{Rp} 33.329 .603$.

Tabel 1. Indikator ketiga jenis makanan

\begin{tabular}{lccc}
\hline \multirow{2}{*}{ Indikator } & Makanan & Makanan & Makanan \\
& $\mathrm{A}$ & $\mathrm{B}$ & $\mathrm{C}$ \\
\hline Permintaan (unit/tahun) & 500 & 800 & 1250 \\
Biaya Pesan (Rp per sekali pesan) & 125.000 & 115.000 & 100.000 \\
Fraksi Penyimpanan Barang (per & 0,8 & 0,9 & 0,95 \\
unit/tahun) & & & \\
Harga Jual Barang ketika akan & 9.500 & 7.750 & 13.500 \\
kedaluwarsa (Rp/unit) & 50 & 100 & 150 \\
Biaya Kekurangan (Rp per unit) & 0,75 & 0,84 & 0,81 \\
Fraksi barang baik ( $\left.\theta_{l}\right)$ & \multicolumn{3}{c}{$\mathrm{Rp} 275.000$} \\
\hline $\begin{array}{l}\text { Biaya Pemesanan secara bersama- } \\
\text { sama }\end{array}$ & \multicolumn{4}{c}{} \\
\hline
\end{tabular}

Tabel 2. Harga penawaran tiap unit yang diberikan oleh distributor untuk ketiga jenis makanan

\begin{tabular}{cccccc}
\hline \multicolumn{2}{c}{ Makanan A } & \multicolumn{2}{c}{ Makanan B } & \multicolumn{2}{c}{ Makanan C } \\
\hline Jumlah & Harga (Rp) & Jumlah & Harga (Rp) & Jumlah & Harga (Rp) \\
\hline$\leq 115$ & 11.500 & $\leq 175$ & 9.500 & $\leq 250$ & 15.000 \\
$>115$ & 10.000 & $>175$ & 8.000 & $>250$ & 14.000 \\
\hline
\end{tabular}

Tabel 3. Besarnya biaya total persediaan untuk masingmasing jenis makanan

\begin{tabular}{crcc}
\hline Jenis makanan & $Q$ & $Q_{k}$ & $T A C(\mathrm{RP})$ \\
\hline A & 129 & 32 & 6.030 .958 \\
$\mathrm{~B}$ & 176 & 29 & 7.572 .318 \\
$\mathrm{C}$ & 251 & 48 & 19.726 .326 \\
& TOTAL $T A C$ & & 33.329 .603 \\
\hline
\end{tabular}


Selanjutnya akan dianalisa besarnya biaya total persediaan yang dikeluarkan oleh perusahaan jika melakukan kebijakan pemesanan barang secara bersama-sama (joint order) dengan menggunakan algoritma di atas.

Jika persamaan (5) digunakan, maka nilai $T^{*}$ pada berbagai kombinasi tingkat harga pembelian dirangkum dalam Tabel 4.

Banyaknya jumlah pemesanan untuk masingmasing jenis makanan dan biaya total persediaan yang dikeluarkan oleh perusahaan selama setahun pada berbagai kombinasi tingkat harga pembelian dirangkum dalam Tabel 5 .

Dari Tabel 5, diperoleh biaya total persediaan yang minimun dengan kebijakan joint order adalah $\mathrm{Rp}$ 32.030.260 dengan jumlah pemesanan masingmasing jenis makanan adalah $Q_{A}=122$ unit, $Q_{B}=$ 194 unit, dan $Q_{C}=304$ unit.

Jumlah barang yang akan kedaluwarsa dari masingmasing jenis makanan pada berbagai kombinasi tingkat harga pembelian dirangkum dalam Tabel 6 .

Tabel 4. Nilai $T^{*}$ berbagai kombinasi tingkat harga pembelian

\begin{tabular}{ccccc}
\hline \multirow{2}{*}{ No } & \multicolumn{3}{c}{ Harga (Rp) } & \multirow{2}{*}{$T^{*}$ (tahun) } \\
\cline { 2 - 4 } & Makanan A & Makanan B & Makanan C & \\
\hline 1. & 11.500 & 9.500 & 15.000 & 0.2306 \\
2. & 11.500 & 9.500 & 14.000 & 0.2353 \\
3. & 11.500 & 8.000 & 15.000 & 0.2342 \\
4. & 11.500 & 8.000 & 14.000 & 0.2391 \\
5. & 10.000 & 9.500 & 15.000 & 0.2336 \\
6. & 10.000 & 9.500 & 14.000 & 0.2384 \\
7. & 10.000 & 8.000 & 15.000 & 0.2373 \\
8. & 10.000 & 8.000 & 14.000 & 0.2424 \\
\hline
\end{tabular}

Tabel 5. Nilai $Q_{1}$ dan $T A C$ pada berbagai kombinasi tingkat harga pembelian

\begin{tabular}{|c|c|c|c|c|c|c|c|c|}
\hline \multirow[t]{2}{*}{ No } & \multicolumn{3}{|c|}{ Harga makanan(Rp) } & \multicolumn{3}{|c|}{$\begin{array}{c}\text { Jumlah } \\
\text { pemesanan }\end{array}$} & \multirow[t]{2}{*}{$T A C$} & \multirow[t]{2}{*}{ Keterangan } \\
\hline & $\mathrm{A}$ & $\mathrm{B}$ & $\mathrm{C}$ & $Q_{A}$ & $Q_{B}$ & $Q_{C}$ & & \\
\hline 1. & 11.500 & 9.500 & 15.000 & 116 & 185 & 289 & 37.930 .121 & $\begin{array}{l}\text { Tidak ada } \\
Q \text { yang } \\
\text { valid }\end{array}$ \\
\hline 2. & 11.500 & 9.500 & 14.000 & 118 & 189 & 295 & 35.620 .066 & $\begin{array}{l}\text { Hanya } Q_{c} \\
\text { valid }\end{array}$ \\
\hline 3. & 11.500 & 8.000 & 15.000 & 118 & 188 & 293 & 35.685 .179 & $\begin{array}{l}\text { Hanya } Q_{B} \\
\text { valid }\end{array}$ \\
\hline 4. & 11.500 & 8.000 & 14.000 & 120 & 192 & 299 & 33.374 .361 & $\begin{array}{l}\text { Hanya } \\
Q_{B}, Q_{C} \text { valid }\end{array}$ \\
\hline 5. & 10.000 & 9.500 & 15.000 & 117 & 187 & 292 & 36.587 .164 & $\begin{array}{l}\text { Hanya } Q_{A} \\
\text { valid } \\
\text { Hanya }\end{array}$ \\
\hline 6. & 10.000 & 9.500 & 14.000 & 120 & 191 & 299 & 34.276 .481 & $\begin{array}{l}Q_{A}, Q_{C} \\
\text { valid }\end{array}$ \\
\hline 7. & 10.000 & 8.000 & 15.000 & 119 & 190 & 297 & 34.341 .737 & $\begin{array}{l}\text { Hanya } \\
Q_{A}, Q_{B} \\
\text { valid }\end{array}$ \\
\hline 8. & 10.000 & 8.000 & 14.000 & 122 & 194 & 304 & 32.030 .260 & $\begin{array}{l}Q_{A}, Q_{B}, Q_{C} \\
\text { valid }\end{array}$ \\
\hline
\end{tabular}

Dengan demikian jika perusahaan menerapkan kebijakan joint order, maka perusahaan akan melakukan pemesanan untuk ketiga jenis makanan secara bersama-sama setiap 0,2424 tahun (88 hari) dengan jumlah pemesanan masing-masing jenis makanan adalah $Q_{A}=122$ unit, $Q_{B}=194$ unit, dan $Q_{c}=304$ unit serta biaya total persediaan yang dikeluarkan selama 1 tahun adalah Rp 32.030.260,00.

Pada Tabel 5 telah diperoleh nilai $Q_{l}$ untuk masingmasing jenis makanan $\mathrm{A}, \mathrm{B}$, dan $\mathrm{C}$, serta $T A C$ pada berbagai kombinasi tingkat harga pembelian. Jika perusahaan melakukan penawaran terhadap harga pembelian untuk dapat melakukan pembelian pada harga termurah sesuai dengan jumlah pemesanan

Tabel 6. Nilai $Q_{k l}$ pada berbagai kombinasi tingkat harga pembelian

\begin{tabular}{|c|c|c|c|c|c|c|c|c|c|}
\hline \multirow[t]{2}{*}{ No } & \multicolumn{3}{|c|}{ Harga makanan (Rp) } & \multicolumn{3}{|c|}{$\begin{array}{c}\text { Jumlah } \\
\text { pemesanan }\end{array}$} & \multirow[t]{2}{*}{$Q_{k A}$} & \multirow[t]{2}{*}{$Q_{k B}$} & \multirow[t]{2}{*}{$Q_{k C}$} \\
\hline & $\mathrm{A}$ & $\mathrm{B}$ & $\mathrm{C}$ & $Q_{A}$ & $Q_{B}$ & $Q_{C}$ & & & \\
\hline 1. & 11.500 & 9.500 & 15.000 & 116 & 185 & 289 & 29 & 30 & 55 \\
\hline 2. & 11.500 & 9.500 & 14.000 & 118 & 189 & 295 & & & 6 \\
\hline 3. & 11.500 & 8.000 & 15.000 & 118 & 188 & 293 & 30 & 30 & 56 \\
\hline 4. & 11.500 & 8.000 & 14.000 & 120 & 192 & 299 & 30 & 3 & 57 \\
\hline 5. & 10.000 & 9.500 & 15.000 & 117 & 187 & 292 & 30 & 30 & 56 \\
\hline 6. & 10.000 & 9.500 & 14.000 & 120 & 191 & 299 & 30 & 31 & 57 \\
\hline 7. & & & & 119 & 190 & 297 & 3 & & 57 \\
\hline 8. & 10.000 & 8.000 & 14.000 & 122 & 194 & 304 & 31 & 32 & 58 \\
\hline
\end{tabular}

Tabel 7. Nilai $Q_{l}$ dan $T A C$ pada tingkat harga pembelian termurah

\begin{tabular}{cccccccc}
\hline \multirow{2}{*}{ No } & \multicolumn{6}{c}{ Harga makanan (Rp) } & \multicolumn{3}{c}{ Jumlah pemesanan } & \multirow{2}{*}{ TAC } \\
\cline { 2 - 7 } & $\mathrm{A}$ & $\mathrm{B}$ & $\mathrm{C}$ & $Q_{A}$ & $Q_{B}$ & $Q_{C}$ & \\
\hline 1. & 10.000 & 8.000 & 14.000 & 116 & 185 & 289 & 32.033 .122 \\
2. & 10.000 & 8.000 & 14.000 & 118 & 189 & 295 & 32.031 .287 \\
3. & 10.000 & 8.000 & 14.000 & 118 & 188 & 293 & 32.031 .620 \\
4. & 10.000 & 8.000 & 14.000 & 120 & 192 & 299 & 32.030 .477 \\
5. & 10.000 & 8.000 & 14.000 & 117 & 187 & 292 & 32.031 .845 \\
6. & 10.000 & 8.000 & 14.000 & 120 & 191 & 299 & 32.030 .576 \\
7. & 10.000 & 8.000 & 14.000 & 119 & 190 & 297 & 32.030 .777 \\
8. & 10.000 & 8.000 & 14.000 & 122 & 194 & 304 & 32.030 .260 \\
\hline
\end{tabular}

Tabel 8. Nilai $Q_{l}$ dan $T A C$ pada berbagai kombinasi tingkat harga pembelian untuk $S^{*}=\operatorname{Rp} 225.000$

\begin{tabular}{|c|c|c|c|c|c|c|c|c|}
\hline \multirow[t]{2}{*}{ No } & \multicolumn{3}{|c|}{ Harga makanan (Rp) } & \multicolumn{3}{|c|}{$\begin{array}{c}\text { Jumlah } \\
\text { pemesanan }\end{array}$} & \multirow{2}{*}{$T A C$} & \multirow[t]{2}{*}{ Keterangan } \\
\hline & A & B & $\mathrm{C}$ & $Q_{A}$ & $Q_{B}$ & $\overline{Q_{C}}$ & & \\
\hline 1. & 11.500 & 9.500 & 15.000 & 105 & 167 & 261 & 7.702 .399 & $\begin{array}{l}\text { Hanya } \\
Q_{A}, Q_{B} \text { valid }\end{array}$ \\
\hline 2. & 11.500 & 9.500 & 14.000 & 107 & 171 & 267 & 35.396 .884 & $\begin{array}{l}Q_{A}, Q_{B}, Q_{C} \\
\text { valid }\end{array}$ \\
\hline 3. & 11.500 & 8.000 & 15.000 & 106 & 170 & 265 & 35.460 .984 & $\begin{array}{l}\text { Hanya } Q_{A} \\
\text { valid }\end{array}$ \\
\hline 4. & 11.500 & 8.000 & 14.000 & 109 & 174 & 271 & 33.154 .779 & $\begin{array}{l}\text { Hanya } \\
Q_{A}, Q_{C} \text { valid }\end{array}$ \\
\hline 5. & 10.000 & 9.500 & 15.000 & 106 & 170 & 265 & 36.362 .350 & $\begin{array}{l}\text { Hanya } Q_{B} \\
\text { valid }\end{array}$ \\
\hline 6. & 10.000 & 9.500 & 14.000 & 108 & 172 & 270 & 34.056 .267 & $\begin{array}{l}\text { Hanya } Q_{B}, Q_{C} \\
\text { valid }\end{array}$ \\
\hline 7. & 0.000 & 8.000 & 15.000 & 108 & 172 & 269 & 34.120 .496 & $\begin{array}{l}\text { Tidak ada } Q \\
\text { yang valid }\end{array}$ \\
\hline 8. & 10.000 & 8.000 & 14.000 & 110 & 176 & 275 & 31.813 .694 & $\begin{array}{l}\text { Hanya } Q_{B}, Q_{C} \\
\text { valid }\end{array}$ \\
\hline
\end{tabular}


pada berbagai kombinasi tingkat harga pembelian, maka besarnya biaya total persediaan yang dikeluarkan dirangkum pada Tabel 7.

Pada Tabel 7, biaya total persediaan yang paling murah adalah pada jumlah pemesanan masingmasing jenis makanan $Q_{A}=122$ unit, $Q_{B}=194$ unit, dan $Q_{c}=304$ unit serta biaya total persediaan yang dikeluarkan selama 1 tahun adalah $\mathrm{Rp}$ 32.030.260. Jadi untuk contoh masalah di atas dengan menerapkan kebijakan joint order, perusahaan dapat mengeluarkan biaya total persediaan yang lebih kecil daripada menerapkan kebijakan individual order dan besarnya perbedaan biaya total persediaan dari kedua kebijakan tersebut adalah $\mathrm{Rp}$ 1.299.343.

Ilustrasi keluaran hasil untuk contoh kasus di atas dengan besarnya biaya pemesanan secara joint order yang berbeda-beda. Ilustrasi ini diberikan pada Tabel 8 - Tabel 10.

Tabel 9. Nilai $Q_{l}$ dan $T A C$ pada berbagai kombinasi tingkat harga pembelian untuk $S^{*}=\operatorname{Rp} 245.000$

\begin{tabular}{|c|c|c|c|c|c|c|c|}
\hline \multirow[t]{2}{*}{ No } & \multicolumn{3}{|c|}{ Harga makanan (Rp) } & \multicolumn{2}{|c|}{$\begin{array}{c}\text { Jumlah } \\
\text { pemesanan }\end{array}$} & \multirow[t]{2}{*}{$T A C$} & \multirow[t]{2}{*}{ Keterangan } \\
\hline & $\mathrm{A}$ & $\mathrm{B}$ & $\mathrm{C}$ & $Q_{A}$ & $Q_{B} \quad Q_{C}$ & & \\
\hline 1. & 11.500 & 9.500 & 15.000 & 109 & 175273 & 37.796 .253 & $\begin{array}{l}\text { Hanya } \\
Q_{A}, Q_{B} \text { valid }\end{array}$ \\
\hline 2. & 11.500 & 9.500 & 14.000 & 112 & 178278 & 35.488 .867 & $\begin{array}{l}\text { Hanya } \\
Q_{A}, Q_{C} \text { valid }\end{array}$ \\
\hline 3. & 11.500 & 8.000 & 15.000 & 111 & 177277 & 35.553 .385 & $\begin{array}{l}\text { Hanya } \\
Q_{A}, Q_{B} \text { valid }\end{array}$ \\
\hline 4. & 11.500 & 8.000 & 14.000 & 113 & 181283 & 33.245 .278 & $\begin{array}{l}Q_{A}, Q_{B}, Q_{C} \\
\text { valid }\end{array}$ \\
\hline 5. & 10.000 & 9.500 & 15.000 & 111 & 177276 & 36.455 .006 & $\begin{array}{l}\text { Tidak ada } Q \\
\text { yang valid }\end{array}$ \\
\hline 6. & 10.000 & 9.500 & 14.000 & 113 & 181282 & 34.147 .027 & $\begin{array}{l}\text { Hanya } Q_{C} \\
\text { valid }\end{array}$ \\
\hline 7. & 0.000 & 8.000 & 15.000 & 113 & 180281 & 34.211 .679 & $\begin{array}{l}\text { Hanya } Q_{B} \\
\text { valid }\end{array}$ \\
\hline 8. & 10.000 & 8.000 & 14.000 & 115 & 184287 & 31.902 .950 & $\begin{array}{l}\text { Hanya } Q_{B}, Q_{C} \\
\text { valid }\end{array}$ \\
\hline
\end{tabular}

Tabel 10. Nilai $Q_{l}$ dan $T A C$ pada berbagai kombinasi tingkat harga pembelian untuk $S^{*}=\operatorname{Rp} 300.000$

\begin{tabular}{|c|c|c|c|c|c|c|c|c|}
\hline \multirow[t]{2}{*}{ No } & \multicolumn{3}{|c|}{ Harga makanan (Rp) } & \multicolumn{3}{|c|}{$\begin{array}{c}\text { Jumlah } \\
\text { pemesanan }\end{array}$} & \multirow[t]{2}{*}{$T A C$} & \multirow[t]{2}{*}{ Keterangan } \\
\hline & A & B & $\mathrm{C}$ & $Q_{A}$ & $Q_{B}$ & $Q_{C}$ & & \\
\hline 1. & 11.500 & 9.500 & 15.000 & 121 & 193 & 302 & 38.036 .189 & $\begin{array}{l}\text { Tidak ada } Q \\
\text { yang valid }\end{array}$ \\
\hline 2. & 11.500 & 9.500 & 14.000 & 123 & 197 & 308 & 35.724 .019 & $\begin{array}{l}\text { Hanya } Q_{C} \\
\text { valid }\end{array}$ \\
\hline 3. & 11.500 & 8.000 & 15.000 & 123 & 196 & 306 & 35.789 .605 & $\begin{array}{l}\text { Hanya } Q_{B} \\
\text { valid }\end{array}$ \\
\hline 4. & 11.500 & 8.000 & 14.000 & 125 & 200 & 313 & 33.476 .638 & $\begin{array}{l}\text { Hanya } Q_{B}, Q_{c} \\
\text { valid }\end{array}$ \\
\hline 5. & 10.000 & 9.500 & 15.000 & 122 & 196 & 305 & 36.691 .877 & $\begin{array}{l}\text { Hanya } Q_{A} \\
\text { valid }\end{array}$ \\
\hline 6. & 10.000 & 9.500 & 14.000 & 125 & 200 & 312 & 34.379 .052 & $\begin{array}{l}\text { Hanya } \\
Q_{A}, Q_{C} \text { valid }\end{array}$ \\
\hline 7. & 0.000 & 8.000 & 15.000 & 124 & 199 & 310 & 34.444 .786 & $\begin{array}{l}\text { Hanya } \\
Q_{A}, Q_{B} \text { valid }\end{array}$ \\
\hline 8. & 10.000 & 8.000 & 14.000 & 127 & 203 & 317 & 32.131 .131 & $\begin{array}{l}Q_{A}, Q_{B}, Q_{C} \\
\text { valid }\end{array}$ \\
\hline
\end{tabular}

Dari hasil-hasil ilustrasi ini dapat dikatakan, bahwa semakin kecil biaya pemesanan secara joint order menyebabkan pembelian masing-masing barang dengan biaya termurah menjadi tidak valid lagi. Hal ini akan menyebabkan kebijakan pemesanan secara joint order dengan nilai $S^{*}$ yang kecil akan lebih mahal dibandingkan kebijakan joint order dengan nilai $S^{*}$ yang lebih besar. Sebagai contoh, pada Tabel 8 dengan $S^{*}=$ Rp 225.000 akan memberikan biaya total persediaan untuk kebijakan joint order yang lebih mahal dibandingkan $S^{*}=\mathrm{Rp} 245.000$ dan $S^{*}=$ Rp 300.000 (Tabel 9 dan Tabel 10). Namun pada Tabel 9 dengan $S^{*}=$ Rp 245.000, pembelian masing-masing barang dengan harga pembelian termurah tidak valid, tetapi dapat digunakan kombinasi pada tingkat harga untuk masing-masing barang jenis $\mathrm{A}, \mathrm{B}$, dan $\mathrm{C}$ berturut-turut adalah Rp 11.500, Rp 8.000, dan Rp 14.000 dengan biaya pemesanan joint order yang masih lebih murah daripada pemesanan secara individual order. Hal ini dikarenakan terdapat penghematan yang signifikan pada biaya simpan dan biaya pesan walaupun untuk biaya pembelian, biaya kekurangan, dan biaya kedaluwarsa kebijakan joint order akan lebih mahal dibandingkan kebijakan individual order.

\section{Simpulan}

Pada makalah ini telah dikembangkan suatu model persediaan multi item dengan mempertimbangkan faktor kedaluwarsa dan faktor all unit discount secara bersama-sama. Melalui model persediaan ini, suatu perusahaan dapat memiliki alternatif kebijakan pemesanan barang apakah dengan kebijakan individual order atau dengan kebijakan joint order. Keputusan untuk memilih kebijakan yang akan digunakan dapat dilakukan dengan melihat biaya total persediaan dari masing-masing kebijakan yang memberkan biaya total persediaan yang minimum. Pengembangan lebih lanjut untuk penelitian lanjutan dapat dilakukan dalam beberapa aspek antara lain membentuk model persediaan untuk barang-barang yang selalu mengalami perishable dari hari ke hari, misalkan pada produk buah-buahan, melibatkan persediaan multi item dengan faktor incremental discount secara bersamaan, ataupun model persediaan probabilistik dengan tetap melibatkan faktor kedaluwarsa dan all unit discount atau incremental discount.

\section{Daftar Pustaka}

1. Bukhari, F., Adaptive Control of a ProductionInventory Model with Uncertain Deterioration Rate, Applied Matehematics, 2, 2011, pp.11701174.

2. Ferguson, M., Jayaraman, V., and Souza, G. C., Note: An Application of the EOQ Model with 
Nonlinear Holding Cost to Inventory Management of Perishables, European Journal of Operations Research, 180, 2007, pp. 485-490.

3. Hariga, M. A., Al-Ahmari, A., and AbdelRahman M. A., A Joint Optimisation Model for Inventory Replenishment Product Assortment, Shelf Space and Display Area Allocation Decisions, European Journal of Operations Research, 181, 2007, pp. 239-251.

4. Indrianti, N., Ming, T., dan Toha, Isa S., Model Perencanaan Kebutuhan Bahan dengan Mempertimbangkan Waktu Kedaluwarsa Bahan, Media Teknik, 2, 2001, pp. 60-65.

5. Kasthuri, R., Vasanthi, P., Ranganayaki S., and Seshaiah, C. V., Multi-Item Fuzzy Inventory Model Involving Three Constrain: A KarushKuhn-Tucker Conditions Approach, American Journal of Operations Research, 1, 2011, pp. 155-159.

6. Limansyah, T., Analisis Model Persediaan Barang EOQ dengan Mempertimbangkan Faktor Kedaluwarsa dan Faktor All Unit Discount, Lembaga Penelitian dan Pengabdian kepada Masyarakat, Universitas Katolik Parahyangan, 2011.
7. Muckstadt, J. A., and Sapra, A., Principles of Inventory Management, Springer, New York, 2010.

8. Prasetyo, H., Munawir, H., dan Musthofiyah, Ning A., Pengembangan Model Persediaan dengan Mempertimbangkan Waktu Kedaluwarsa Bahan dan Faktor Incremental Discount, Jurnal Ilmiah Teknik Industri, 4(2), 2005, pp. 49-56.

9. Prasetyo, H., Nugroho, Munajat T., dan Pujiarti A., Pengembangan Model Persediaan Bahan Baku dengan Mempertimbangkan Waktu Kedaluwarsa dan Faktor Unit Diskon, Jurnal Ilmiah Teknik Industri, 4(3), 2006, pp. 115-122.

10. Tersine, R. J., Principles of Inventory and Material Management, $4^{\text {th }}$ ed., Prentice Hall, New Jersey, 1994.

11. Zhang B., and Du, Shaofu, Multi-Product Newsboy Problem with Limited Capacity and Outsourcing, European Journal of Operations Research, 202, 2010, pp. 107-113

12. Zhang, B., and Wang, X., Optimal Policy and Simple Algorithm for a Deteriorated Multi-Item EOQ Problem, American Journal of Operations Research, 1, 2011, pp. 46-50. 